Nama : Gabriel David P S

NRP : 130218261

Mata Kuliah : Perekonomian Indonesia

$\mathrm{KP}: \mathrm{B}$

\title{
Indonesia's Efforts to Achieve Globally Competitive Human Resources
}

In 2017 Indonesia received a Human Development Index Score (HDI) with a number of 70.81, this number shows that Indonesia's HDI can be said to be high because the general value category is 70.00 but there are still scores with low HDI in 18 provinces such as Papua, Papua. West, and East Nusa Tenggara. The main reason is the difficulty of access to schools. On the other hand, it is also caused by high infant mortality as well as government policies that have not prioritized human resource development. Poverty is a very complicated problem in this country. This poverty occurs because of the quality factor of human resources that are still not qualified, but on the other hand shows that there has been an improvement in human resources. The government is still trying to stay focused on work programs aimed at reducing the number of poverty. It is undeniable that poverty can simply disappear without improving access, quality and education gaps. It can be seen that five million school-age children who should receive education but do not experience education itself. Improving the quality of learning must continue to be done to improve human resources. In the company, there are still many employees who are principled as followers and tend to wait for others first. Individuals in each employee must be given insight into things that are nobler than money and rank. On the other hand, the goal is to make it easier for employees to collaborate without being forced to remember that employee loyalty can produce significant results. Innovation in products is also not always done alone but can also collaborate with partners or even carry out win-win solutions with other business partners to support product creativity. As a company leader, you have a big responsibility within the company itself as well as encouraging individuals to make a company that moves forward together. Building a vision and mission of an advanced company and with individuals within the company. As a leader, you must also have a positive aura so that all employees can have more motivation in running the company's organization. PT Telkom develops human resources by building character, competence, collaboration, and teamwork to produce many talents and market assessments to achieve progress. PT. PELINDO IV initiates the development of human resources through strengthening corporate culture and corporate values by prioritizing changes in behavior and mindset. Employee competency improvement is carried out through training programs and customer care officers. Based on the company's values, the Pelindo IV Way was formed which contains the company's vision which becomes the compass and direction of all employees' work activities in daily life.

(Gora, Tayibnapis, \& Wuryaningsih, 2018)

\section{The Development of Digital Economy in Indonesia}

Indonesia has entered the 4.0 era, this era is an era where new technology is able to change the entire chain and management in every branch of the industry. For example the financial industry is commonly known as financial technology and digital banking. Currently, technology-based financial services have grown rapidly in Indonesia. This rapid growth is marked by the emergence of startup companies, such as payment systems and money transfer 
services, savings and loans, insurance, financial information service providers, capital markets, crowdfunding. This rapid change can show that technology can play a strategic role in providing financial services. This is in line with consumers where consumers can be served without having to come to the office or they can be served through accessible technology features. Availability The availability of digital banking services and products is highly valued by customers, both individuals and business actors, especially in Micro, Small and Medium Enterprises (MSMEs). Rapid technology in the banking world is now present including internet banking, mobile banking, AMS banking, ATM, e-money, phone-banking, payment galleries, branchless banking, online debit, digital outlets, virtual credit cards, cash management systems, EDC, mobile branches, mobile accounts and smartphone-based financial applications. With the presence of the various features above, it is intended that consumers continue to be motivated to become loyal customers and become part of a modern lifestyle. Indonesia's future economic growth requires a strong and stable financial sector at $6 \%$ per year. On the other hand, banks, insurance, capital markets and company startups must be encouraged so that annual credit growth is no longer in the 10-12\% range. This is intended so that the capacity of the financial sector can increase five times from its current position, as has been achieved by Singapore and Thailand. However, it is important to note that financial services are vulnerable to cyber crime which is a result of the rapid development of technology. The public is also not fully educated about cyber crimes. Digital technology has proven to play a strategic role in providing goods and services in a convenient, practical, cheaper, faster, and labor-intensive way. The availability of banking/nonbanking products and services that use digital technology is highly appreciated by the public, both individuals and businesses, including MSMEs.

(Gora, Tayibnapis, \& Wuryaningsih, The Development of Digital Economy in Indonesia, 2018)

\section{Companies in Indonesia in the vortex of global economic disruption}

Throughout 2018, various efforts were made to continuously improve the ranking of convenience for the community to have a business. However, in 2018 it was also still stuck with exports and imports which have consistently tended to decline since 2015 . According to the world bank report on the ease of doing business for the community in 2018 Indonesia was in position 73 out of 190. The position decreased from 2017 where Indonesia's rank was still at 72. This downgrade is not expected to have a significant impact on investment. In 2018 global economic conditions tended to be sluggish and unbalanced, this was followed by high global financial uncertainty. In the era of economic disruption, it is estimated that until 2020 this requires business people to continue to develop and innovate so that they can survive in the market. Viewed from 2014 to 2017, there was an increase in the population of large and medium-sized industries, starting from 25,094 business entities in 2014 to 30,992 business entities in 2017 , or an increase of 5,898 business entities. The small industrial sector also experienced an increase, from 3.52 million business entities in 2014 to 4.49 million business entities in 2017, or an increase from 970 thousand small business entities for 4 years. The Central Government and Regional Governments are trying to realize various infrastructure projects, but at the same time, digital technology is growing massively which has an impact on the creation of new jobs which is reflected in the indicators of job opportunities that go up. What employees currently have may not be needed in the future, so new competencies are needed. The competitiveness of companies in Indonesia in Indonesia in the face of economic disruption and the industrial revolution and 4.0 is actually very dependent on the ability to take advantage of 
changes along with technological advances that have increased exponentially in order to survive, develop, and provide added value for all stakeholders.

(Tayibnapis, Wuryaningsih, \& Gora, 2019) 


\section{DAFTAR PUSTAKA}

Bibliography

Gora, R., Tayibnapis, A. Z., \& Wuryaningsih, L. E. (2018). Indonesia's Efforts to Achieve Globally Competitive Human Resources. International Journal of Humanities and Social Science Invention (LJHSSI), 1-6.

Gora, R., Tayibnapis, A. Z., \& Wuryaningsih, L. E. (2018). The Development of Digital Economy in Indonesia. International Journal of Management \& Business Studies, 14-18.

Tayibnapis, A. Z., Wuryaningsih, L. E., \& Gora, R. (2019). Companies in Indonesia in the vortex of global economic disruption. 174-177. 



\section{JAWABAN UAS PEREKONOMIAN INDONESIA KP B}

1. transformasi UMKM perlu dilakukan dan harus terus diperkuat melalui optimalisasi penggunaan teknologi digital sehingga dapat menarik manfaat dari salah satu pelajaran utama krisis kesehatan, yaitu penggunaan teknologi digital untuk kegiatan sehari-hari. Perkembangan ekonomi dan keuangan digital yang pesat telah menumbuhkan berbagai platform digital yang menawarkan inovasi dalam kegiatan produksi, konsumsi, kolaborasi, dan berbagi. Digitalisasi tersebut memberikan peluang kepada UMKM untuk beradaptasi dan bertransformasi untuk bisa bertahan dan bangkit serta tumbuh lebih tinggi, disertai dengan peningkatan korporatisasi, kapasitas, dan pembiayaan. penggunaan digital dalam memenuhi kebutuhan konsumsi, kegiatan produksi, maupun transaksi investasi. Dengan demikian, pemanfaatan platform digital dapat mendorong UMKM yang lebih kuat melalui peningkatan kapasitas yang lebih produktif dan inovatif serta memfasilitasi perluasan akses UMKM baik pada marketplace, industri, dan lembaga keuangan.

2. UMKM tidak bisa dipandang sebelah mata karena jumlahnya sangat banyak. Dan memang mampu sebagai pendorong pertumbuhan ekonomi. Dapat dilihat pada situs Bappenas, di Indonesia UMKM memiliki kontribusi atau peranan cukup besar, yaitu: Perluasan kesempatan kerja dan penyerapan tenaga kerja. Pembentukan Produk Domestik Bruto (PDB). Penyediaan jaring pengaman terutama bagi masyarakat berpendapatan rendah untuk menjalankan kegiatan ekonomi produktif. Berdasarkan data Kementerian Koperasi dan UKM Republik Indonesia, Sensus Ekonomi dari Badan Pusat Statistik pada 2016 menunjukkan besarnya kontribusi UMKM. Antara lain: UMKM menyerap hingga 89,2 persen dari total tenaga kerja. UMKM menyediakan hingga 99 persen dari total lapangan kerja. UMKM menyumbang 60,34 persen dari total PDB nasional. UMKM menyumbang 14,17 persen dari total ekspor. UMKM menyumbang 58,18 persen dari total investasi.

3. karena UMKM memiliki peran penting dalam perekonomian dan berpotensi untuk terus ditingkatkan dalam mendorong pertumbuhan ekonomi nasional. UMKM juga memiliki ketahanan ekonomi yang tinggi sehingga mendukung stabilitas perekonomian. Disisi lain juga Pengembangan UMKM juga merupakan bagian dari upaya mendukung stabilitas sistem keuangan.

4. UMKM Indonesia telah memasuki era 4.0, era ini merupakan era dimana teknologi baru mampu mengubah seluruh mata rantai dan manajemen di setiap cabang industri. Misalnya industri keuangan yang biasa dikenal dengan financial technology dan digital banking. Saat ini, layanan keuangan berbasis teknologi telah berkembang pesat di Indonesia. Pertumbuhan pesat ini ditandai dengan munculnya perusahaan-perusahaan rintisan, seperti sistem pembayaran dan layanan pengiriman uang, simpan pinjam, asuransi, penyedia layanan informasi keuangan, pasar modal, crowdfunding. Perubahan yang cepat ini dapat menunjukkan bahwa teknologi dapat memainkan peran strategis dalam menyediakan layanan keuangan. Hal ini sejalan dengan konsumen dimana konsumen dapat dilayani tanpa harus datang ke kantor atau dapat dilayani melalui fitur teknologi yang dapat diakses. Availability Ketersediaan layanan dan produk perbankan digital sangat dihargai oleh nasabah, baik individu maupun pelaku usaha, terutama di Usaha Mikro, Kecil dan Menengah (UMKM). Teknologi pesat di dunia perbankan kini hadir diantaranya internet banking, mobile banking, AMS banking, ATM, e-money, phone-banking, payment gallery, branchless banking, online debit, digital outlet, virtual credit card, cash 
management system, EDC , cabang seluler, akun seluler, dan aplikasi keuangan berbasis ponsel cerdas. Dengan hadirnya berbagai fitur di atas, dimaksudkan agar konsumen terus terpacu untuk menjadi pelanggan setia dan menjadi bagian dari gaya hidup modern. Pertumbuhan ekonomi Indonesia ke depan membutuhkan sektor keuangan yang kuat dan stabil sebesar $6 \%$ per tahun. Di sisi lain, perbankan, asuransi, pasar modal, dan perusahaan rintisan harus didorong agar pertumbuhan kredit tahunan tidak lagi di kisaran 10-12\%. Hal ini dimaksudkan agar kapasitas sektor keuangan dapat meningkat lima kali lipat dari posisinya saat ini, seperti yang telah dicapai oleh Singapura dan Thailand. Namun, penting untuk dicatat bahwa layanan keuangan rentan terhadap kejahatan dunia maya yang merupakan hasil dari perkembangan teknologi yang pesat. Masyarakat juga belum sepenuhnya teredukasi tentang kejahatan siber. Teknologi digital terbukti berperan strategis dalam menyediakan barang dan jasa secara nyaman, praktis, murah, cepat, dan padat karya. Ketersediaan produk dan layanan perbankan/non-perbankan yang menggunakan teknologi digital sangat diapresiasi oleh masyarakat, baik individu maupun bisnis, termasuk UMKM.

5. UMKM dinilai menjadi kunci keberhasilan pemerintah untuk memulihkan ekonomi. Pentingnya upaya mendorong Transformasi UMKM harus diperkuat karena sejalan dengan besarnya kontribusi sektor ini terhadap perekonomian nasional. Berdasarkan data pada tahun 2019 sektor UMKM memberikan kontribusi 60,34 persen terhadap produk domestik bruto (PDB) nasional, atau atau Rp694 triliun.

Sektor yang memiliki jumlah 64,2 juta unit usaha UMKM ini juga mampu menyerap sekitar 116 juta tenaga kerja atau sekitar 97,02 persen dari total angkatan kerja nasional. 